12 Marchbanks, R. M., J. Neurochem., 13, 1481 (1966).

13 Curtis, D. R., and Crawford, J. M., Ann. Rev. Pharmacol., 9, 209 (1969).

14 . Horita, A., J. Neuropsychiat., 4, 270 (1963).

is Balestrieri, A., and Fontanari, D., Arch. Gen. Psychiat., 1, 279 (1959).

16 Isbell, H., Wolbach, A. B., Wikler, A., and Miner, E. J., Psychopharmacologia, 2, 147 (1961).

17 Wolbach, A. B., Isbell, H., and Miner, E. J., Psychopharmacologia, 3, 1 (1962).

8 Wolbach, A. B., Miner, E. J., and Isbell, H., Psychopharmacologia, 3, 219 (1962).

19 Diab, I. M., Freedman, D. X., and Roth, L. J., Science, 173, 1022 (1971).

\section{Liver Zinc in Carcinoma}

IN contrast to the important role of zinc in wound healing ${ }^{1,2}$ comparatively little attention has been paid to the metal in relation to tissue reaction to malignant disease ${ }^{3-8}$. In this study samples of liver tissue from fifty necropsies were divided into four series (excluding malignant tissue itself): "normal" liver (series I), fatty liver (series II), apparently uninvaded liver from organs containing secondary malignant deposits (series III) and livers from patients with malignant disease but no obvious liver secondaries (series IV). The selection, preliminary processing and preparation of the specimens will be described elsewhere $^{9}$. All specimens were analysed in duplicate. One set of samples was wet-digested and used for the measurement of
Table 2 Two Examples of the Zinc-concentration Gradient in Livers containing Malignant Deposits

$\begin{array}{lcc} & \text { Ash zinc (p.p.m.) } \\ \text { Liver } A & \text { Liver } B \\ \text { Necrotic core of tumour } & 4,000 & 2,850 \\ \text { Periphery of tumour } & 5,000 & 3,850 \\ \text { Apparently normal tissue adjacent to tumour } & 11,800 & \\ \text { Apparently normal tissue remote from tumour } & 12,300 & 7,900\end{array}$

pretations. A "premalignant state" associated with a considerable accumulation of zinc in the tissues might be widespread in patients who die from the disease. More probably, the increase in liver zinc could reflect a defence reaction to invasion by malignant cells. This could apply even to organs which contained no naked-eye deposits. (A link may exist between the role of zinc in wound healing and the accumulation of zinc in tissues reacting to malignant disease.) Last, it is conceivable though unlikely that the rise in liver zinc might be associated with the poor nutritional state common in the terminal stage of cancer rather than with the cancer itself. (The relation between general nutritional state and zinc is still unclear; but, on circumstantial evidence ${ }^{2,16}$, in malignant cachexia one might expect a decrease rather than an increase in tissue zinc.) The striking accumulation of an easily measurable trace metal in the liver in malignant disease might be of diagnostic use in the interpretation of liver-biopsy material.

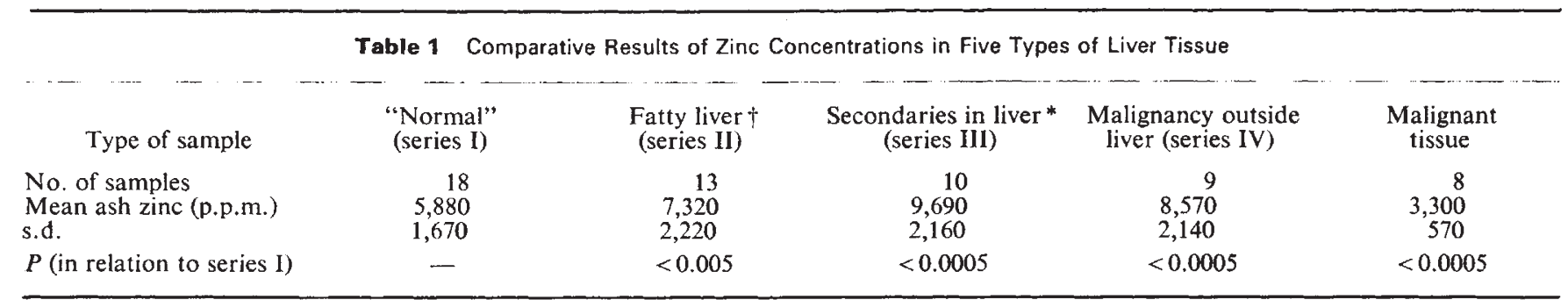

* All samples were removed from uninvaded areas which showed no naked-eye or microscopic evidence of malignancy.

$\uparrow$ Liver fat estimated by method based on ref. 10 .

zinc concentration by atomic-absorption spectroscopy. The other set of samples was ashed and used for the determination of the wet-weight/ash ratio. Closely adjacent specimens were examined microscopically to exclude histological evidence of local malignant invasion. Zinc concentrations were finally expressed in terms of ash weight tissue. (In this context this is a more meaningful reference datum than "dry" weight, wet weight or protein or nitrogen concentration.) The results are summarized in Table 1. "Normal" liver (series I) refers to organs which had been removed from subjects who showed no evidence of malignant disease anywhere, and whose liver showed only mild terminal changes. The range of zinc concentrations in this series was comparatively narrow and is in fairly close agreement with the findings of other workers ${ }^{3+11-15}$. The difference between normal liver zinc and liver zinc from subjects with malignant disease (series III and IV) was highly significant $(P<0.005$ and $P<0.0025$ respectively). The difference between the two malignant-disease series was insignificant compared to the difference between the two malignant-disease series combined on the one hand and the two non-malignant series combined on the other.

Carcinomatous deposits themselves had a low zinc concentration both in terms of mean concentration and of range of values (mean: 3,300 p.p.m.; range: $250-4,440$ p.p.m.). Because of this and because of the abnormally high zinc content of organs harbouring such deposits there was a steep zincconcentration gradient when samples were analysed moving from the necrotic core of a secondary growth to the apparently uninvaded surrounding tissue (Table 2).

The high zinc concentration in apparently unaffected liver tissue from subjects with carcinoma is open to several inter-
We thank the British Empire Cancer Campaign for Research for financial support, and the staff of the Clinical Pathology Unit, Whittington Hospital, for help.

\section{E. B. WRIGHT}

T. L. DORMANDY

Department of Chemical Pathology,

Whittington Hospital,

London N19

Received October 5; revised December 7, 1971.

${ }^{1}$ Pories, W. J., Henzel, J. H., Rob, C. G., and Strain, W. H., Ann. Surg., 165, 432 (1967)

2 Underwood, E. J., Trace Elements in Human and Animal Nutrition, third ed. (Academic Press, New York, 1971).

${ }^{3}$ Koch, H. J., Smith, E. R., and McNeely, J., Cancer, 10, 151 (1957).

${ }^{4}$ Vikbladh, I., Scand. J. Clin. Lab. Invest., 3, Suppl. 2 (1951).

5 Vallée, B. L., and Gibson, J. G., J. Biol. Chem., 176, 445 (1948).

${ }^{6}$ Hoare, R., Delory, G. E., and Penner, D. W., Cancer, 9, 721 (1956).

7 Addink, N. W. H., and Frank, L. J. B., Cancer, 12, 544 (1959).

8 Davies, I. J. T., Musa, M., and Dormandy, T. L., J. Clin. Pathol., 21, 359 (1968)

9 Wright, E. B., thesis, IMLT London (1971).

10 Van de Kamer, J. H., Huinink, H., and Weyers, H. A., J. Biol. Chem., 177, 347 (1949).

11 Eggleton, W. G., Biochem. J., 34, 991 (1940).

12 Olson, K. B., Heggen, G., Edwards, C. F., and Gorham, L. W., Science, 119, 772 (1954).

13 Butt, E. M., Nusbaum, R. E., Gilmour, T. C., and DiDio, S. L., Amer. J. Clin. Pathol., 24, 385 (1954).

14 Kahnke, M. J., Atomic Absorption Newsletter, 5, 1 (1966).

15 Netsky, M. G., Harrison, W. W., Brown, M., and Benson, C., Amer. J. Clin. Pathol., 51, 358 (1969).

16 Prasad, A. S., Halstead, J. A., and Nadimi, M., Amer. J. Med., 31. 532 (1961). 